\title{
Research on the Construction of Applied Specialty in Science and Engineering
}

\author{
Fan Linan \\ Department of Automation Professional of SHEN YANG \\ University \\ SHEN YANG University \\ Shen Yang 110044, China \\ linanfan@163.com
}

\author{
Pan Xiaodong \\ Department of Psychology of SHEN YANG University \\ SHEN YANG University \\ Shen yang 110044, China \\ 782024347@QQ.com
}

\author{
Zhang Ming \\ Department of Electronic Information Science and Technology \\ SHEN YANG University \\ Shen Yang 110044, China \\ Zhming1963@163.com
}

\begin{abstract}
In order to study the construction of applied specialty, this paper explores the application of the talents in the process of the rapid development of higher education, and designs the corresponding personnel training program according to the specifications of the applied talents, and constructs the applied professional personnel training system Involving many aspects of the problem. The basic orientation of applied undergraduate colleges is to serve the local economy and cultivate advanced applied talents. To complete the training objectives, application-oriented professional training should be targeted from the target, curriculum system, teaching staff, practice system reform and practice. This paper discusses the reform and practice of the goal of personnel training, curriculum system, teaching staff and practice system to get conclusion about the professional of application teaching standards and curriculum standards.
\end{abstract}

Keywords-Construction; Specialty; Science; Engineering;

\section{INTRODUCTION}

Application-oriented professional should update the concept of personnel training, reform personnel training mode, deepen the teaching practice. Application - oriented specialty should emphasize the innovation and application of professional construction; Application-oriented professional should implement the professional education and engineering practice ability to connect the talent training program, and strive to build a local characteristics, to the application of professional personnel training, both research and innovationoriented professional training "module + platform + capacity "The personnel training system; Application of professional should focus on training, rational construction, the establishment of a "double teacher" the quality of the professional teaching team to build undergraduate application of professional curriculum system to improve students' professional skills and professionalism.

\section{THE GENERAL IDEA OF APPLICATION - ORIENTED PROFESSIONAL CONSTRUCTION}

Professional construction to cultivate students' practical ability and innovative spirit as the main line, adhere to the "three combined" [1] .That is, the combination of theoretical teaching and practical teaching, the combination of engineering and training and project design, combined with innovative practice and scientific research, from the focus on knowledge transfer to pay more attention to the ability and quality of training changes. To further update the teaching concept, sort out the reform ideas. And strive to explore and build a "cultivate engineering awareness, build engineering capacity, to obtain certification" that "awareness - ability • certification" of the application of innovative talent training model, And focus on the Internet + innovative talent training program; Strengthen the foundation, professional, research three experimental platform, to improve the innovation system and innovation base construction. To create a better teaching environment, improve the quality of teaching, and cultivate the application type, adaptable, innovative talents. The overall idea mainly includes the following:

\section{A. The use of professional characteristics, with forward- looking and personalized training programs}

To the purpose of "teaching students in accordance with their aptitude", students under the guidance of their own disciplines, according to their own conditions and social needs, determine the major professional courses, emphasizing the practical ability of engineering, with cutting-edge knowledge and business docking with the compulsory modules and elective courses to develop flexible a variety of innovative training programs [2]. 


\section{B. Reform the curriculum system and teaching content}

Adhere to the teaching content and the overall optimization of the curriculum system principles, to deal with the pattern of personnel training, training objectives and teaching content and curriculum system, traditional content and modern content, inheritance and innovation, foundation and application, impart knowledge and improve the relationship between the ability [3] .The curriculum content of the curriculum and the curriculum system in-depth research and reform practice, strengthen the foundation, broaden the professional caliber, build a modular curriculum system set up to strengthen the school is to cooperate with the construction of teaching courses, the overall optimization of the curriculum content, so that the curriculum knowledge structure more Reasonable, more richer, novel.

\section{To cultivate practical ability and innovative spirit as the core, strengthen the three-level experimental teaching platform system}

Improve the "basic", "professional" and "research" three experimental teaching platform system construction, create excellent engineering innovation environment, carry out various forms of scientific and technological innovation activities and applied research engineering training. Emphasis on student-oriented, students choose Design, commissioning, testing and summary report, give full play to students 'selfinitiative and creativity, improve students' engineering quality, and continue to strengthen the three-level experiment.

\section{Pay attention to quality courses, excellent courses, three- dimensional teaching materials}

Excellent courses and excellent courses can reflect the modern education and teaching ideas, to promote the overall quality of students' development, reform the school education environment, is conducive to promoting higher education and teaching reform. Has completed a provincial and multi-level above the boutique courses, rich boutique course site, the curriculum standards (syllabus), lesson plans, exercises, experimental guide materials and reference bibliography and all the Internet, to achieve high quality teaching resources to share. Organize teachers to actively prepare teaching materials, the development of multimedia courseware, the construction of three-dimensional teaching materials [4] .

\section{E. Strengthen the team of teachers and teaching and research team}

To the teaching and research section for the construction unit to a series of courses or professional for the construction platform, training more teaching teachers, strengthen the teaching team building, so that the team has a good spirit of cooperation and echelon structure, old and young with, title and knowledge structure is reasonable, and Guide and encourage young teachers to continuously improve the professional quality and operational level.

\section{APPLICATION-ORIENTED TALENTS TRAINING MODE REFORM}

\section{A. Implementation of the "school - enterprise cooperation, work and study" talent training mode}

To serve the regional economic construction as the goal, cultivate innovative, complex, applied talents. To explore the "school-enterprise cooperation, work and study," the talent training model, the four-year training period is divided into seven modules, including basic skills, professional skills, comprehensive skills 3 modules in schools, internships, social practice, production practice, Internship 4 modules in the enterprise. Through the professional skills training and training, training professional practice and engineering awareness through the practice of internships and internships, to improve the job capacity and production awareness, so that the professional quality and quality of professional knowledge and skills through the professional basic skills and skills; Ability training systematization, concrete, explore and form the quality and skills both work and study of talent training model. Market-oriented, and actively explore the school and enterprise to build courses, cooperation in training personnel, to build a joint laboratory and practice base, so that skills training and technical training targeted to cultivate a rapid adaptation of the work of complex, applied talents [5] .

\section{B. Promote the Training Mode of Applied Innovative Talents}

To further update the teaching concept, to clarify the reform ideas, and strive to explore and build a "cultivate engineering awareness, build engineering capacity, to obtain certification" that "awareness - ability - certification" of the application of innovative talent training model. Based on the requirements of professional job capacity, professional skills certification requirements and teaching content of the depth of integration. Students can combine professional requirements and personal career planning, from the circuit debugging, computer-aided design, electronic design and development, electronic assembly and commissioning, computer programming and other senior specialized personnel in the selection of training and research, training practice and engineering Awareness, improve professional skills and work competitiveness.

\section{Improve the innovation awareness and engineering capacity training system}

To "apply" talent training as the core, strengthen the foundation, professional, research three experimental platforms. System, and fully build the "innovation leading group + innovation interest group + innovation base + open management mechanism + innovation activities" scientific and technological innovation training system. Attract students to enter the laboratory open topics, participate in scientific research projects, to participate in a variety of professional skills competitions, certification training, etc., for students to accept the second classroom capacity training. 


\section{Curriculum Construction And Teaching Content REFORM}

\section{A. Curriculum Content and Curriculum System Reform}

In the new construction program, the construction of practical teaching and school-based curriculum content and system construction will be to build a typical technology, typical design process or product as the main line of engineering courses system to solve the curriculum structure, content and personnel training type To solve the problem, to build a project as a unit to a typical product design as the carrier of the course content structure, to solve the professional theory and practice of segmentation, teaching content and business needs. To break the traditional purely subject teaching model, based on the conduct of enterprise research, invite enterprises to participate in the first-line staff to discuss the project topics, content and implementation of programs and objectives to determine the professional to cultivate the core knowledge system, key practical skills and important professional Quality, reconstruction of the subject curriculum system, based on the design process and project-oriented practice teaching curriculum system, according to professional core competencies, to determine the corresponding core curriculum. Electronic information engineering professional curriculum system will be in the product design, simulation, production, assembly, measurement and other links to product design as a carrier, throughout the teaching links, to build a "task-centered" project structure, to achieve teaching The model consists of the teacher as the center to the student as the center of the conversion, to build the new curriculum system to adapt to the implementation of the teaching system for the implementation of the new curriculum system to lay a good foundation for the realization of core competencies to provide a solid support and protection.

Through the integration of curriculum integration, reflecting the product design, implementation and its computer and Internet technology through, to reflect the engineering awareness, engineering capacity and certification skills, the proportion of theory and practice appropriate, operational implementation of undergraduate advanced applicationoriented personnel training courses System and its curriculum standards.

Curriculum system (macro): the overall structure, theoretically strengthen the basic knowledge, practice focus on practical application;

Curriculum construction: project application case (project) as the core; project-oriented curriculum objectives, the project involved and the need for theoretical knowledge and skills for the task-driven teaching, to achieve the theory of practice with understanding, practice deepening theoretical understanding, improve students' practical design And the development of the ability to cultivate the goal of applied talents.

The introduction of engineering standards and procedures; increase the proportion of practice links, the integration of the existing part of the curriculum, to open a comprehensive ability training courses; reflect the theoretical study and related unit design and curriculum integration design integration; Type of personnel training objectives.

\section{B. The Construction of Practical Teaching System}

Change the past theory, practice the separation of teaching methods to project design to build the situation, practice training process around a task or project to organize teaching, while doing learning, while learning to do, learn to learn one. According to the principle of "task-driven, project-oriented", the professional teachers and business engineers to complete the above stages of the teaching work and organize the implementation of the development of the task-oriented project courses to explore the "teaching, learning, do integration" Teaching methods, the formation of process monitoring as the main features of the assessment methods, and ultimately explore the appropriate electronic information engineering education curriculum development and teaching model. Around the personnel training objectives and specifications, to build disciplines professional "431" practice teaching system. 1 refers to the first line: the ability to train the main line; 3 refers to the three: around the ability to train the main line, the ability to segment the basic skills, comprehensive application and design capabilities, research and innovation ability of three levels of capacity training system, Is the fourth layer: the basis of discipline, professional basis, professional core, application to improve, in accordance with the experimental teaching and theoretical teaching synchronization, experimental teaching for the ability to train services, experimental and practical teaching is divided into four levels of practical teaching system [6] .

\section{EXPERIMENTAL AND TRAINING CONDITIONS}

\section{A. Construction of training base in school}

Through the reorganization and rational distribution of resources, focusing on the construction of internal engineering training center, requires students to master the theoretical knowledge at the same time, experimental and practical handson training, training students practical technical ability. Support the students' extracurricular activities group to carry out the project practice activities, competition, participate in teacher teaching and research activities. In the construction of the emphasis on innovation, comprehensive open features, emphasizing the practicality of engineering education for students to create conditions for innovation and production.

\section{B. Construction of outside training base}

The formation of a number of distinctive off-campus training base. Teachers and business technical personnel of each other, enterprises involved in school-enterprise cooperation, build an outdoor training base, sharing the existing production equipment, and actively cultivate enterprises in urgent need of talent.

\section{Training base connotation construction}

The establishment of the school, outside the training base operation and management system, the implementation of the base to the person in charge, and signed a project mission.

Through the construction, improve the long-term mechanism of school-enterprise cooperation, the revised viable and effective base operation and management system, professional teachers, part-time teacher management system, 
student internship management system, student training assessment system, and enterprises signed long-term training base agreement, To meet the requirements of major skills training and technical innovation services.

And strive to cooperate with enterprises, the development of scientific and technological innovation projects, to lead students to carry out scientific and technological innovation activities to promote teachers' scientific research activities and the level of ability to improve the project into results, services in local industrial development and economic construction.

\section{SUMMARY}

Through the transformation of the development of professional construction, and industry enterprises in the field of personnel training, technology development and application of cooperation in areas such as the use of undergraduate education to create the characteristics and brand, explore and develop the development of professional standards and curriculum standards, Within the same institutions and related professional groups to produce radiation and lead role.

\section{REFERENCES}

[1] Wu qiong, "Exploration on the Reform of Innovative Practice Teaching System of Electronic Information," yatai education, Sichuan Province12 $2^{\text {th }}$ 2016., In Chinese.

[2] Chen yao, "Exploration of Practical Teaching in Electronic Information Teaching in Colleges and Universities", Research on curriculum education, 3rd 2016. In Chinese.

[3] liuyang. On the Construction of "Signal Detection and Processing" in Journal of Shenyang University: Social Science Edition", 2010, 12 (1): 92-94 In Chinese.

[4] Zhangming." Research on the Construction of Innovation Education Curriculum System in Science and Engineering", Advances in Social Science, Education and Humanities Research,2016.12:P 44-48

[5] Wu gang. "Exploration of Single Chip Computer Teaching and Experiment Method Reform", Education Abstracts,2013.,9 In Chinese.

[6] Chenyao. "Discussion on the Strategy of Promoting Teaching Reform in Colleges and Universities by Using Modern Information Technology", Technology Outlook,2016.06, In Chinese. 